\title{
Tumor Antigens Discovery: Perspectives for Cancer Therapy
}

\author{
Rong-Fu Wang \\ National Cancer Institute, National Institutes of Health, \\ Bethesda, Maryland, U.S.A.
}

\begin{abstract}
The adoptive transfer of cytotoxic T lymphocytes (CTLs) derived from tumor-infiltrating lymphocytes (TIL) along with interleukin 2 (IL-2) into autologous patients with cancer resulted in the objective regression of tumor, indicating that these CTLs recognized cancer rejection antigens on tumor cells. To understand the molecular basis of $\mathrm{T}$ cell-mediated antitumor immunity, several groups started to search for such tumor antigens in melanoma as well as in other types of cancers. This led to the subject I will review in this article. A number of tumor antigens were isolated by the use of cDNA expression systems and biochemical approaches. These tumor anti-
\end{abstract}

gens could be classified into several categories: tissuespecific differentiation antigens, tumor-specific shared antigens, and tumor-specific unique antigens. However, the majority of tumor antigens identified to date are nonmutated, self proteins. This raises important questions regarding the mechanism of antitumor activity and autoimmune disease. The identification of human tumor rejection antigens provides new opportunities for the development of therapeutic strategies against cancer. This review will summarize the current status and progress toward identifying human tumor antigens and their potential applications to cancer treatment.

\section{INTRODUCTION}

The immune system plays a critical role in immunosurveillance against cancer and in tumor regression. The importance of $\mathrm{T}$ cells in the regression of tumors has been demonstrated in experimental animal tumor models (1-3). Adoptive transfer of tumor-infiltrating lymphocytes (TIL) along with interleukin-2 (IL-2) into the autologous patients resulted in the objective regression of tumor $(4,5)$. To further understand how $\mathrm{T}$ cells mediate antitumor responses and what molecules are recognized by $\mathrm{T}$ cells on tumor cells, a great deal of effort has been made to identify tumor antigens recognized by cytotoxic $\mathrm{T}$ lymphocytes (CTLs) with antitumor reactivity in vivo and in vitro. This has resulted in the molecular identification of a number of tumor

Address correspondence and reprint requests to: Dr. Rong-Fu Wang, National Cancer Institute, Building 10/Rm 2B42, Bethesda, MD 20814, U.S.A. Phone: 301-496-1437; Fax: 301-496-0011; E-mail: rongfu@nih.gov antigens in the past few years. These studies have provided the basis for understanding $\mathrm{T}$ cell-mediated antitumor activity, and a rationale for the development of anticancer vaccines. Clinical trials using peptides derived from the identified tumor antigens have shown promising results in the treatment of patients with melanoma. Recombinant viruses expressing tumor antigens combined with cytokines and costimulatory molecules are being evaluated for the potential therapeutic effect.

\section{APPROACHES TO IDENTIFICATION OF HUMAN TUMOR ANTIGENS}

\section{Genetic Approach}

The first approach is to transfect recombinant genomic DNA or cDNA libraries into cells expressing the appropriate MHC molecule. This 
system was recently improved by the use of cDNA libraries that are transfected transiently into COS or 293 cells along with a cDNA encoding the appropriate MHC molecule $(6,7)$. Positive clones are identified on the basis of the ability to stimulate cytokine release from CTL. This simple and powerful approach has led to the identification of many genes encoding tumor antigens (7-16). Major drawbacks of this approach include the possibility of identifying cDNA clones that encode cross-reacting peptides recognized by $\mathrm{T}$ cells due to a high expression level in COS system, and the need to identify the antigenic peptides from the amino acid sequence of the antigenic proteins.

\section{Peptide Isolation}

$\mathrm{T}$ cells recognize a peptide bound to the MHC class I molecule. Tumor-specific peptides can be eluted with acid from either the tumor cell surface or purified peptide-MHC complexes, and they can be separated subsequently by highpressure liquid chromatography (HPLC). The eluted peptide fractions are then tested for their ability to stimulate cytokine secretion from CTL when pulsed onto MHC-matched antigen-presenting cells (APC). If the amount of peptide in the positive fraction is sufficient to allow sequence determination by Edman degradation, a naturally processed, tumor-specific peptide recognized by CTL can be directly identified (17). The peptide sequence can then be used to search databases to find the gene encoding the antigenic peptide. Drawbacks to this approach include the technical complexities associated with fractionation of the active peptides and the use of instruments such as tandem mass spectrometry.

It is worth noting that synthetic peptide libraries based on the peptide binding motif of a particular MHC molecule have been used for identification of an antigenic peptide recognized by CTL (18). However, the identified peptide may be a cross-reactive peptide, rather than an authentic peptide derived from a tumor antigen.

\section{"Reverse Immunology" Approach}

In some cases, no tumor-reactive CTL exists. For example, it is relatively difficult to generate breast tumor-reactive CTL from a patient, but there is a putative tumor antigen whose expression is known to be associated with tumor $(19,20)$. To prove that this is a true tumor antigen, it is necessary to generate CTLs in vitro using peptides derived from a putative tumor antigen (19-23). However, in many cases, these CTLs do not recognize the tumor cells because of the $\mathrm{T}$ cell receptors (TCR) with low affinity to the peptides. Alternatively, the peptide recognized by CTLs in in vitro systems may not be naturally processed and presented on the tumor cell surface. Although significant progress has been made in understanding the rules of peptidebinding motifs for different MHC molecules (24), the predicted peptides that contain the MHCbinding motif may not, however, be naturally processed and presented on tumor cells at sufficient levels to be recognized by $\mathrm{T}$ cells. Use of antigen-presenting cells pulsed with peptide or protein, or transfected with a cDNA encoding the putative tumor antigen as stimulators, should be subjected to further investigation.

\section{TUMOR ANTIGENS RECOGNIZED BY T CELLS}

\section{Tissue-Specific Shared Differentiation Antigens}

Five tissue-specific shared tumor antigens including tyrosinase, MART-1/Melan-A, gpl00, TRP-1, and TRP-2 have been identified by TIL which induced tumor regression when administered to autologous patients along with IL-2 (Table 1). Thus, they may represent tumor rejection antigens. These antigens were expressed in melanoma, normal melanocytes, and retina, but not in other normal human tissues.

TYROSINASE. Tyrosinase is the first member of differentiation antigens identified and is an important enzyme involved in the synthesis of melanin $(6,25)$. Two distinct epitopes, MLLAVLYLL and YMNGTMSQV, were identified from the tyrosinase molecule and recognized by CTLs in the context of HLA-A2 (26). The tyrosinase antigen was also shown to be recognized by an HLAA24-restricted TIL888 that had been previously shown to result in the regression of multiple metastatic lesions when adoptively transferred into the autologous patient along with IL-2 (12). In addition, the peptide SEIWRDIDF derived from the tyrosinase protein was recognized by HLA-B44-restricted T cells (27). Interestingly, a naturally processed HLA-A2-associated peptide YMDGTMSQV was identified by peptide elution and mass spectrometry. This peptide results from the post-translational conversion of asparagine 
TABLE 1. Tissue-specific differentiation antigens

\begin{tabular}{|c|c|c|c|}
\hline Antigens & $\underset{\text { restrictions }}{\text { HLA }}$ & Peptides & Comments \\
\hline \multirow[t]{6}{*}{ Tyrosinase } & HLA-A2 & MLLAVLYCL & \\
\hline & HLA-A2 & YMNGTMSQV & \\
\hline & HLA-B44 & SEIWRDIDF & \\
\hline & HLA-A24 & AFLPWHRLF & \\
\hline & HLA-DR4 & QNILLSNAPLGPQFP & \\
\hline & HLA-DR4 & SYLQDSDPDSFQD & \\
\hline MART-1/Melan-A & HLA-A2 & AAGIGILTV & \\
\hline \multirow[t]{7}{*}{ gP100 } & HLA-A2 & KTWGQYWQV & \\
\hline & HLA-A2 & ITDQVPFSV & \\
\hline & HLA-A2 & YLEPGPVTA & \\
\hline & HLA-A2 & LLDGTATLRL & \\
\hline & HLA-A2 & VLYRYGSFSV & \\
\hline & HLA-A3 & ALLAVGATK & \\
\hline & HLA-A2 & VYFFLPDHL & $\begin{array}{l}\text { Epitope generated from an intron of an } \\
\text { incomplete splicing RNA }\end{array}$ \\
\hline gP75/TRP-1 & HLA-A31 & MSLQRQFLR & Epitope was derived from an alternative ORF \\
\hline TRP-2 & HLA-A31 & LLGPGRPYR & $\begin{array}{l}\text { Mouse TRP- } 2 \text { was identified as a tumor antigen } \\
\text { for B } 16 \text { melanoma }\end{array}$ \\
\hline
\end{tabular}

to aspartic acid (28). These results indicate that multiple epitopes and modified peptides can be generated from the same molecule and be presented to $\mathrm{T}$ cells by different MHC class I-restricted molecules.

While the role of $\mathrm{CD}^{+} \mathrm{T}$ cells in tumor rejection has been well documented, $\mathrm{CD}^{+} \mathrm{T}$ cells may also play an important role in antitumor immune responses. First, many melanoma cell lines express MHC class II molecules and are capable of presenting the antigenic peptides to $\mathrm{CD}^{+} \mathrm{T}$ cells. Second, CD4 ${ }^{+}$TIL derived from both melanoma and breast cancers have been shown to respond to the autologous tumor cells $(29,30)$. For example, it was shown that the $\mathrm{CD}^{+}$melanomareactive TIL 1088 recognized antigenic peptides derived from the tyrosinase protein in an HLADR4-restricted fashion $(31,32)$. Two distinct peptides, QNILLSNAPLGPQFP and DYSYLQDSDP DSFQD, were identified to be recognized by the $\mathrm{CD}^{+}$TIL 1088 (33). Therefore, the tyrosinase gene product contains multiple $\mathrm{CD}^{+} \mathrm{T}$ cell epitopes as well as $\mathrm{CD}^{+} \mathrm{T}$ cell epitopes. The existence of other MHC class II-restricted tumor antigens from melanoma and breast cancers was recently reported $(29,30,34)$. Studies directed toward identifying MHC class II-restricted tumor antigens are currently in progress.
MART-1/MELAN-A. The MART-1 gene was isolated by screening of a melanoma cDNA library with the HLA-A2-restricted melanoma-reactive TIL 1235 (35). MART-1 is identical to Melan-A independently cloned by another group (7). The MART-1 cDNA isolated from melanoma cells did not contain any mutation or other alterations in the coding region. Northern blot analysis indicated that MART-1 was expressed only in melanomas, melanocytes, and retina, but not in normal human tissues (35). The MART-1 gene product was found to be an immunodominant melanoma antigen recognized by the majority of HLA-A2-restricted melanoma-reactive CTL established from TIL in the Surgery Branch, NCI $(35,36)$, as well as a large percentage of melanoma reactive clones derived from the peripheral blood lymphocytes (PBL) of HLA-A2 ${ }^{+}$melanoma patients (37). One 9-mere peptide, AA GIGELTV (M9-27), was found to be recognized by HLA-A2-restricted melanoma-specific CTL (36). Although MART-1 is a dominant antigen recognized by many HLA-A2-restricted TIL, no correlation was found between $\mathrm{T}$ cell recognition of MART-1 and clinical response. In contrast, a strong correlation was found between the $\mathrm{T}$ cell recognition of gp100 and clinical response (38). 
Some TILs recognize both MART-1 and gpl00 (38).

GP 100. A cDNA clone encoding gpl00 was isolated and shown to be almost identical to Pmel17, which had previously been cloned using anti-melanoma antibodies (39-41). Northern blot analysis demonstrated that gpl00 was expressed in neonatal cultured melanocyte lines, most melanoma cell lines, and retina, but not in other normal tissues (40). The gpl00 molecule was found to be recognized by 8 out of 21 HLAA2-restricted melanoma-reactive TIL established from different patients with melanoma in the Surgery Branch, NCI, and appears to represent a highly immunogenic antigen. Some CTL lines can recognize multiple gp100 epitopes. Many gp100 epitopes have been identified by CTLs derived from different patients $(38,40,42)$. Recently, a HLA-A3-restricted epitope was identified from the normal coding sequence of gpl00 (43).

One of the gp 100 epitopes, YLEPGPVTA, was independently isolated from an HPLC-purified fraction of peptides obtained from HLA-A2-positive melanoma (44). This observation validates both genetic and biochemical approaches to the identification of naturally processed peptides on tumor cells.

TRP-1/GP75. While all antigenic peptides discussed above were identified from the normal open reading frame, $\mathrm{T}$ cells are also capable of recognizing antigenic peptides from an alternative open reading frame or an intron of an mRNA transcript (Table 1). Several examples have recently been reported.

Previous studies showed that TIL586 derived from patient 586 recognized one or more antigens in the context of HLA-A31 (45). A tumor antigen encoded by TRP-1/gp75 was isolated following cDNA library screening. Interestingly, gp75 was previously reported to be recognized by IgG antibodies in the serum of a patient with melanoma (46). Northern blot and protein analysis indicated that the gp75 protein was one of the most abundant intracellular glycoproteins in melanocyte-lineage cells, but it was not detected in non melanocytic cell types $(45,47,48)$. The gp75 molecule has recently been shown to have DHI-2-carboxylic acid oxidase activity involved in the synthesis of melanin (49). To identify the epitope in gp75, DNA deletion constructs were made to localize an antigenic peptide to a small DNA fragment. A number of peptides were syn- thesized on the basis of the predicted amino acid sequence of gp75 and the peptide binding motif for HLA-A31 (50). None of the peptides tested were found to stimulate cytokine release from TIL586 when pulsed onto HLA-A31-positive EBV-transformed B cells (51). However, two ATG start codons were present in different open reading frames relative to the normal gp75 ORF1 reading frame (Fig. 1). To explore this possibility, three peptides derived from ORF2 and two peptides from ORF3 were selected and synthesized on the basis of the HLA-A31 binding motif. Surprisingly, the peptide MSLQRQFLR, which was derived from ORF3, was capable of stimulating cytokine release from TIL586 when pulsed onto HLA-A31-positive EBV-transformed B cells (Fig. 2) (51). This represents one of the first examples of two overlapping open reading frames being used to translate two distinct polypeptides from a single eukaryotic cellular mRNA, although translation of overlapping reading frames has been reported in viral mRNAs (52-54). These results demonstrated a novel mechanism by which a human tumor antigen can be generated from an alternative open reading frame and presented to $\mathrm{T}$ cells by an MHC class I molecule.

Several related examples of the use of alternative open reading frames have also been reported recently. p16 $6^{\mathrm{INK} 4 \mathrm{a}}$ was demonstrated to encode an inhibitor of the cyclin D-dependent kinases CDK4 and CDK6 (55). pl6 probably acts as a tumor suppressor since deletions and mutations of this gene were found in a variety of tumors (56). Interestingly, a second gene product was recently identified from an alternative open reading frame of the mouse $\mathrm{p} 16^{\text {INK4a }}$ gene to encode a $19 \mathrm{kDa}$ (pl9ARF) protein (57). The ectopic expression of pl9ARF in fibroblasts was found to induce G1 and G2 phase arrest. Therefore, the pl6 gene encodes two dissimilar proteins, both of which may be required for cell cycle regulation. In another study, a truncated cDNA encoding $\alpha$-tubulin was isolated from a mouse spleen cDNA library using lacZ-inducible $\mathrm{T}$ cells as a probe (58). Deletion and mini-gene constructs with an ATG start codon in frame with the $\alpha$-tubulin failed to identify the epitope recognized by $\mathrm{T}$ cells. However, a peptide derived from a non-ATG-defined alternative open reading frame was found to be recognized by $\mathrm{T}$ cells, suggesting that a cryptic translation product may also be presented to $\mathrm{T}$ cells by an MHC class I molecule. In another study, a gpl00 epitope recognized by HLA-A2-restricted CTL cloids was 


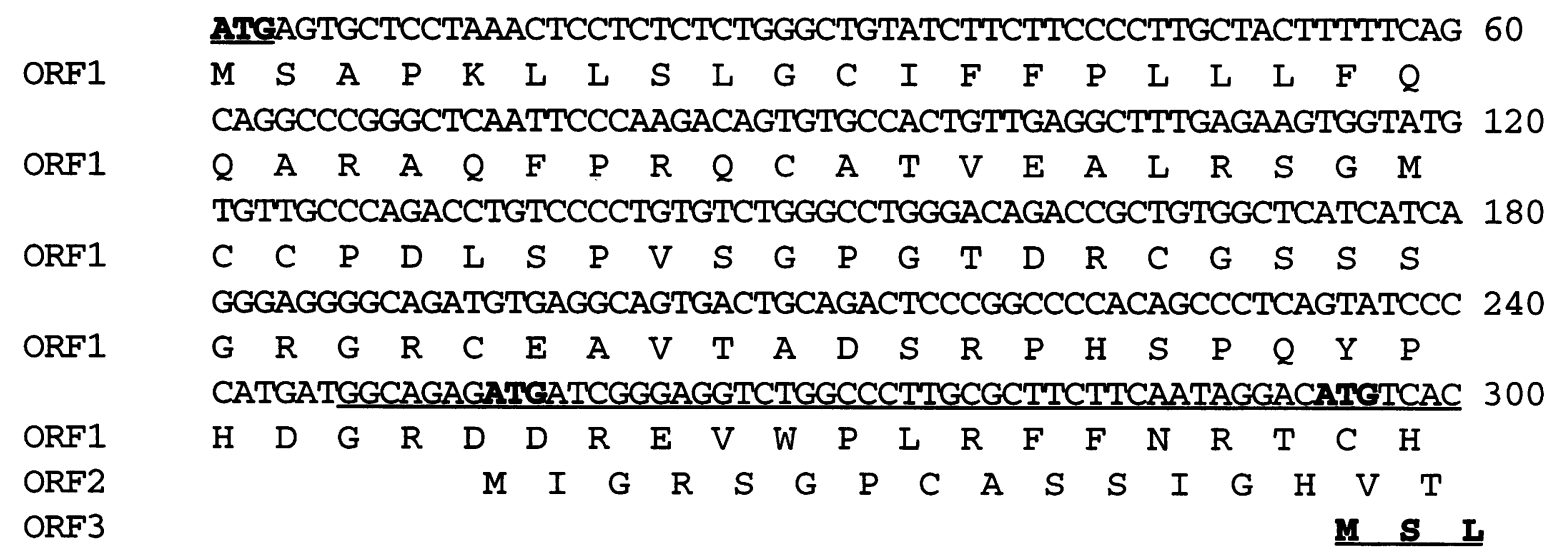

ORF1 TGCAACGGCAATTTCTCAGGACACAACTGTGGGACGTGCCGTCCTGGCTGGAGAGGAGCT 360

ORF2

ORF3

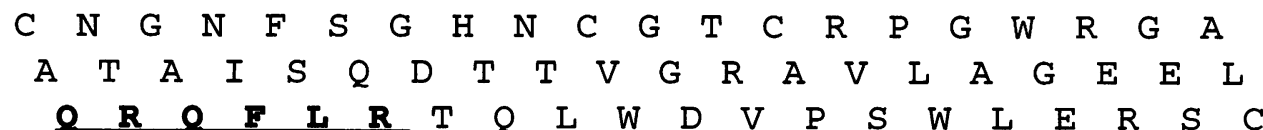

GCCTGTGACCAGAGGGTTCTCATAGTCAGGAGAAATCTTCTGGACTTAAGTAAAGAAGAA 420

ORF1

ORF2

ORF3

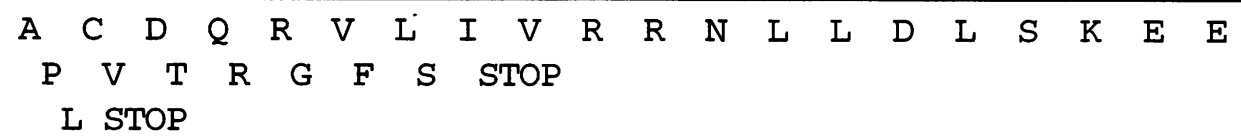

ApaI

AAGAACCACTTTGTCCGGGCCCTGGATATGGCAAAGCGCACAACTCACCCT. . ATATGA 1584

ORF1

$\begin{array}{llllllllllllllllll}K & N & H & F & V & R & A & L & D & M & A & K & R & T & T & H & P\end{array}$

FIG. 1. The nucleotide, amino acid sequence, and open reading frames of the gp75 gene

The partial nucleotide and amino acid sequences of the first 157 amino acids are shown from the start codon for translation of ORFl (gp75). The DNA fragment that conferred the ability to stimulate GM-CSF release from TIL586 is underlined. Two putative start codons, ATG (254-256) and ATG (294-296), are in bold and may result in the translation of ORF2 and ORF3, respectively. The peptide sequence recognized by TIL586 from ORF3 is in bold and underlined.

identified from an intron of an incomplete splicing form of the gp100 RNA (59).

TRP-2. Since TIL586 has antitumor activity in vivo, it is possible that TIL586 consists of oligoclonal $\mathrm{T}$ cell populations that recognize multiple tumor antigens. To test whether TRP-1/gp75 was the only antigen recognized by TIL586, a number of CTL clones were established from TIL586. The recognition pattern of CTL clones from TIL586 could be classified into several categories: the first class of CTL clones recognized TRP-1/gp75, 586mel, and HLA-A31 positive melanocytes; the second class of CTL clones did not recognize TRP$1 / g p 75$, but strongly recognized autologous tumor and HLA-A31 positive normal melanocytes, suggesting that these CTL clones recognized a new antigen; the third class of CTL clones recognized autologous tumor, but neither TRP-1/gp75 nor HLA-A31 positive normal melanocytes. This led to identification of TRP-2 as a tumor antigen recognized by CTL clones from TIL586 (Table 1) (16). TRP-2 is a member of the tyrosinase-related protein family and has approximately $40-45 \%$ of amino acid sequence identity to tyrosinase or TRP-1/gp75. An antigenic peptide was then identified from the normal open reading frame of TRP-2. Interestingly, a mouse TRP-2 was identified as a tumor antigen recognized by CTL reactive with Bl6 melanoma (60). This represents the first example of which both human and mouse TRP-2 act as tumor antigens. Therefore, the mouse TRP-2 can be tested as an ideal antigen in studies important for human cancer vaccines.

To broad clinical utilities of tumor antigens such as TRP-1 and TRP- 2 that are restricted by HLA-A31, it is important to identify $T$ cell 
TABLE 2. Tumor-specific shared antigens

\begin{tabular}{|c|c|c|c|c|c|c|}
\hline \multirow[b]{2}{*}{ Antigens } & \multirow[b]{2}{*}{$\begin{array}{c}\text { HLA } \\
\text { restrictions }\end{array}$} & \multicolumn{2}{|c|}{ Expression patterns ${ }^{a}$} & \multirow[b]{2}{*}{$\begin{array}{c}\text { Breast } \\
(\%)\end{array}$} & \multirow[b]{2}{*}{$\begin{array}{c}\text { Prostate } \\
(\%)\end{array}$} & \multirow[b]{2}{*}{$\begin{array}{c}\text { Bladder } \\
(\%)\end{array}$} \\
\hline & & $\begin{array}{c}\text { Normal } \\
\text { tissues }\end{array}$ & $\begin{array}{c}\text { Melanoma } \\
(\%)\end{array}$ & & & \\
\hline MAGE-1 & HLA-Al, -Cw16 & Testis & 30 & 5 & 15 & 19 \\
\hline MAGE-3 & HLA-A1, -A2 & Testis & 65 & 5 & 15 & 34 \\
\hline BAGE & HLA-Cwl 6 & Testis & 17 & 10 & 0 & 15 \\
\hline GAGE-1 & HLA-Cw6 & Testis & 20 & 0 & 10 & 12 \\
\hline CAG-3/NY-ESO-1 & HLA-A31 & Testis & 35 & 30 & 25 & 80 \\
\hline
\end{tabular}

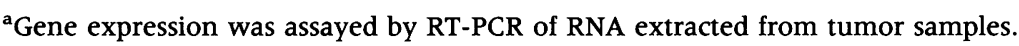

epitopes restricted by other MHC class I alleles. On the basis of structural similarities of a group of HLA allels and peptide binding motifs, several supertypes were proposed (61). The HLA-A31 molecule belongs to a member of the HLA-A-3like supertype that covers $45-50 \%$ of all ethnic populations. In a recent study, it was demonstrated that both TRP- 1 and TRP-2 peptides were capable of binding to HLA-A3, -A11, -A31, -A33 and -A68 (62). Furthermore, the TRP-2 peptide was recognized by $T$ cells in the context of HLAA31 and -A33 (62). These studies raised a possibility that the TRP-1 and TRP-2 peptides could be used in the peptide-based vaccines to treat patients expressing one of the HLA-A3 superfamily members.

\section{Tumor-Specific Shared Antigens}

MAGE-1 AND -3. MAGE-1 was the first tumor antigen identified on a human melanoma using a genetic approach. A genomic library derived from the tumor cell line was transfected into an MHC-matched, antigen-loss variant (8). Stable transfectants were screened by CTLs derived from the melanoma patient who had been repeatedly immunized with mutagenized autologous tumor. MAGE-1 was isolated from the transfectants on the basis of its ability to stimulate cytokine release from the CTLs (8). The peptide epitope EADPTGHSY, was subsequently identified and recognized by CTL in the context of HLA-Al (63). A second antigenic peptide, SAYGEPRKL, was identified from the MAGE-1 protein and recognized by HLA-Cw16-restricted CTLs (64). The MAGE-1 gene is expressed in approximately $30 \%$ of melanomas as well as in other types of tumors (Table 2), but it is not detected in normal human tissues with the exception of testis (8).

DNA hybridization analysis indicated that MAGE- 1 is a member of a multiple-gene family. A similar peptide, EVDPIGHLY, derived from MAGE-3, was shown to be recognized by HLAAl-restricted CTLs (9). The second epitope peptide was identified using HLA-A2-restricted CTLS generated in vitro with a synthetic peptide derived from MAGE-3 (65). Like MAGE-1, MAGE-3 was not expressed in human normal tissues except testis. Because MAGE- 3 expression was detected in approximately $60 \%$ of melanomas, it may represent a good candidate for the development of vaccine strategies.

$B A G E$ AND GAGE. Two additional antigens were identified from a cDNA library made from the same MZ2 melanoma cell line (Table 2). A cDNA clone encoding BAGE was isolated using a class I HLA-Cwl6-restricted $\mathrm{T}$ cell clone derived from the MZ2 patient (11). This gene encodes a polypeptide of 43 amino acids and appears to be expressed in a pattern similar to that of members of the MAGE family. A peptide of nine amino acids was recognized by CTLs in the context of HLA-Cwl6. Using the same approach, a gene encoding an antigen recognized by a class I HLACw6-restricted $\mathrm{T}$ cell clone was isolated. This led to the identification of a new family of genes named GAGE (10). Among them, GAGE-1 and GAGE-2 encoded a peptide that was recognized by CTLs in association with $\mathrm{HLA}-\mathrm{Cw}^{*} 0601$. GAGE genes were found to have an expression 
pattern similar to that of the MAGE and BAGE genes (10).

CAG-3/NY-ESO-1. It was demonstrated that several CTL clones established from TIL586 did not recognize TRP-1 or TRP-2, or normal HLA-A31positive melanocytes, but they still strongly recognized the autologous tumor 586mel (16). After screening a cDNA library, several positive cDNA clones were identified (R. Wang and S. Rosenberg, unpublished data). DNA sequence analysis revealed that this gene is identical to NY-ESO-1, which was recently reported to be recognized by the autologous serum from a patient with esophageal cancer (66). Like members of the MAGE gene family, this gene is not expressed in normal human tissues except testis, but it is highly expressed in melanoma, breast, prostate, bladder, and other types of cancers (Table 2) (R. Wang and S. Rosenberg, unpublished data, 66).

\section{Tumor-Specific Unique Antigens}

Many mutations have been identified from tumor suppressor genes such as ras, $p 53$, and $p 16$ tumor samples. Because the mutated proteins or peptides could be more immunogenic and be seen as foreign by the host immune system, it has long been assumed that many tumor antigens would be mutated antigens recognized by $\mathrm{T}$ cells. Surprisingly, the majority of tumor antigens identified are nonmutated self-proteins. To test whether mutated ras and $p 53$ are tumorspecific antigens, several groups have raised CTLs against normal or mutated peptides from the ras proto-oncogene (67) and $p 53$ tumor suppressor gene $(19,68-71)$. However, in most cases these CTLs failed to recognize tumor cells. One possibility is that peptides selected on the basis of peptide-binding motif are not naturally processed or that the density of MHC-peptide complexes is too low on tumor cells to allow recognition by these CTLs. It should be noted, however, that despite the numerous mutations identified in ras and $p 53$, only a very small subset of mutations enhance, if they are processed, the MHC-binding affinity or T cell recognition. Several mutated gene products have been recently identified as tumor-specific antigens recognized by CTL derived from patients by screening CDNA libraries using reactive CTLs (Table 3 ).

MUM-1 (melanoma-ubiquitous mutated) was isolated following the transient transfection of COS cells with HLA-B44 and pools of cDNAs
TABLE 3. Tumor-specific unique antigens

\begin{tabular}{lll}
\hline Antigens & $\begin{array}{c}\text { HLA } \\
\text { presentation }\end{array}$ & \multicolumn{1}{c}{ Peptides } \\
\hline MUM-1 & HLA-B44 & EEKLIVVLF \\
CDK4 & HLA-A2 & ACDPHSGHFV \\
$\beta$-catenin & HLA-A24 & SYLDSGIHF \\
HLA-A2 & HLA-A2 & Altered HLA-A2
\end{tabular}

derived from the LB33 melanoma cell line. The peptide epitope EEKLIVVLF was found to be recognized by CTL (72). DNA sequence analysis revealed that a point mutation in the sequence of the cDNA isolated from the tumor led to a change of one amino acid (Ser to Ile) at position 5 of the peptide. Since both the normal and mutated peptides bound efficiently to the class I HLA-B44 molecule, but only the mutated form could be recognized by $T$ cells, this indicated that the mutation appeared to have an effect on T cell recognition. Further analysis indicated that the antigenic peptide spanned the intron-exon boundary of an incompletely spliced transcript.

A second mutated gene was isolated from a cDNA library of melanoma patient SK29 (14). This gene encodes cyclin-dependent kinase 4 (CDK4), an enzyme involved in cell cycle control. DNA sequence analysis indicated that a point mutation (a C-to-T transition) led to a substitution of a cysteine for an arginine residue at codon 24. It was found that the mutated peptide was capable of sensitizing the target cells at 100to 1000 -fold lower peptide concentrations than the normal peptide. The CDK4 protein usually forms a complex with cyclin Dl and phosphorylates the pRB protein, and therefore promotes the cell cycle progression from $\mathrm{Gl}$ to $\mathrm{S}$ phase (56). However, assembly of CDK4 with cyclin D1 as well as its kinase activity was found to be inhibited by $\mathrm{pl}^{\mathrm{INK} 4 \mathrm{a}}$. Interestingly, $\mathrm{pl} 6^{\mathrm{INK} 4 \mathrm{a}}$ cannot bind to the mutated CDK4 and fails to inhibit the kinase activity of CDK4/cyclin D, implying that the mutation in the CDK4 gene leads to a loss of cell cycle control.

The mutated $\beta$-catenin gene product was also recently identified and shown to be recognized by TIL 1290 derived from a melanoma patient 888 (15). Partial cDNA sequence analysis indicated that a point mutation was found to be responsible for a change of serine to phenylalanine in the coding region. The mutated $\beta$-catenin 
peptide SYLDSGIHF was found to actively sensitize target cells for lysis at a concentration of $1 \mathrm{pM}$, whereas the normal peptide (SYLDSGIHS) required a much higher peptide concentration to sensitize lysis of target cells. A competitive peptide binding assay indicated that this substitution resulted in an increase in binding affinity of the mutated peptide to the HLA-A24 molecule. The $\beta$-catenin protein has been shown to be a cytoplasmic protein that interacts with the cellular adhesion molecule E-cadherin (73). A number of mutations have been found in the $\beta$-catenin gene product from different tumors $(74,75)$. Loss of cell adhesion molecules may play a role in the metastatic process (76). Recently, three groups reported that the upregulation or stabilization of $\beta$-catenin may contribute to tumorigenesis and cancer progression because of mutations in the adenomatous polyposis coli tumor suppressor protein (APC) or $\beta$-catenin (77-79).

An HLA-A2 mutation was found to be recognized in renal carcinoma cells by CTL. Interestingly, $T$ cells recognized the mutated whole HLA-A2 molecule, instead of recognizing the mutated peptide epitope (80).

\section{Tumor Antigens Ubiquitously Expressed}

The majority of human melanoma antigens identified thus far are tissue-specific. However, one melanoma-specific $\mathrm{T}$ cell line was found to recognize an antigen termed p15, whose expression is ubiquitous in normal tissues (81). A nonmutated peptide, AYGLDFYIL, was identified as a $T$ cell epitope derived from the $\mathrm{p} 15$ protein. It is not clear whether this peptide represents a true $T$ cell epitope or is a cross-reactive one with the product derived from an unknown gene but is still recognized by TIL 1290 on tumor cells. The low level of expression of this antigen in normal tissues may not generate a sufficient amount of MHC-peptide complex on the cell surface to elicit a $\mathrm{T}$ cell response.

HER-2/neu was recently identified as a shared tumor antigen recognized by $\mathrm{T}$ cells in breast and ovarian cancers. The HER-2/neu proto-oncogene encodes a tyrosine kinase protein whose expression has been shown to be increased in $30 \%$ of breast and ovarian cancers. In breast cancer, HER-2/neu overexpression was reported to be associated with aggressive disease. Cytotoxic $\mathrm{T}$ lymphocytes isolated from tumorassociated lymphocytes can specifically recognize a synthetic peptide corresponding to amino acids 971-980 of the HER-2/neu protein (82). This is the first demonstration that CTLs isolated from human tumors recognize HER-2/neu as an ovarian tumor antigen. Recently, four ovarian tumor-reactive CTLs were established from different $\mathrm{HLA}_{-} \mathrm{A}^{+}$patients and were capable of recognizing both freshly isolated HER-2/neu ${ }^{+}$ tumor cells and non-HLA-A2 ovarian tumor lines transfected with HLA-A2 cDNA (20). A common epitope, KIFGSLAFL, was found to be recognized by four of four CTL lines (20). Another epitope peptide (971-980) was also found to be recognized by two of four CTL lines. These results were supported by findings of other groups $(83,84)$. Recognition and lysis of ovarian cancer cells by CTLs were also shown to correlate with the expression level of HER-2/neu in the tumor cells (83). Most importantly, the breast and ovarian cancer-specific CTLs recognized the same epitope peptide (GP2; amino acids 654662 ) derived from the HER-2/neu protein in the context of HLA-A2 $(85,86)$. It appears that the GP2 peptide represents a common epitope shared by different epithelial tumors because it was recognized by CTL lines derived from breast, ovarian, non-small-cell lung and pancreatic cancers (86).

Another tumor antigen in this class is the mucin-associated epitope from the muc-l gene product, whose expression has been shown to be associated with breast and pancreatic adenocarcinomas (87). The $m u c-1$ gene is expressed on epithelial cells, fibroblasts, and B cells, and it can serve as a target for $\mathrm{T}$ cell recognition. However, $\mathrm{T}$ cell recognition of the muc-l gene product appeared to be non-MHC restricted (88). The epitopes for $\mathrm{T}$ cell recognition were found in the tandem repeat of the muc-1 protein (89).

\section{PERSPECTIVES FOR CANCER THERAPIES}

The identification of tumor antigens recognized by $\mathrm{T}$ cells has important implications in the understanding of $\mathrm{T}$ cell-mediated antitumor activity and provides opportunities for the development of new strategies for cancer vaccines. Because the majority of tumor antigens identified thus far are self-proteins, a potential consequence of active immunization with these cancer peptides is the development of autoimmune disease $(90,91)$. Development of vitiligo has been found to be correlated with good prognosis or clinical responses to immunochemotherapy in mela- 
noma patients (92-94). The adoptive transfer of autologous TIL along with IL-2 into patients with melanoma resulted in the objective regression of tumor, but only occasionally resulted in the depigmentation of skin in treated patients, suggesting that the treatment of patients with anti-self $T$ cells does not necessarily cause tissue destruction in normal organs $(40,45)$. Patients developed neither depigmentation nor any retinal tissue destruction after treatment with tyrosinase-specific TILs (95). Recently, Houghton and co-workers have demonstrated that passive immunization with a mouse monoclonal antibody (TA99) against gp75 induced protection against and rejection of the gp75 ${ }^{+}$Bl6F10 melanoma in syngeneic mice (96). There was no evidence of decrease in pigmentation, inflammation, or changes in cellular morphology or tissue architecture in the eyes of mice treated with antibody (96), suggesting that the threshold required for tumor regression is lower than that for normal tissue destruction.

Identification of these new cancer peptides has led to several clinical trials conducted in the Surgery Branch, National Cancer Institute. Active immunotherapy involves the direct immunization of cancer patients with cancer antigens in an attempt to boost immune responses against the tumor. The immunodominant peptides derived from tumor antigens could readily be synthesized in vitro and used for immunization either alone or in a form intended to improve their immunogenicity, such as in combination with adjuvant, linkage to lipids/liposomes or helper peptides, or pulsed onto antigen-presenting cells. It has recently been reported that peptide-pulsed dendritic cells (DC) induce antigen-specific antitumor immune responses in mice (97). Human DC derived from PBMC have been transduced with retroviral vectors encoding tumor antigens and have induced tumor-specific CTL in vitro $(98,99)$. Modification of the immunodominant peptides to improve binding efficiency to MHC antigens can potentially increase immunogenicity and induce stronger antitumor activity. Preliminary studies have indicated that peptide vaccines using gp100 G9-280 or G9-280M peptides combined with IFA result in $40-50 \%$ clinical responses in HLA-A2 ${ }^{+}$melanoma patients (S. Rosenberg, unpublished data). These results are very encouraging; since multiple tumor antigens and multiple epitopes are identified from patients with cancer, it is likely that the use of multiple epitope peptides will enhance antitumor activity.
To prove that the tumor antigens identified thus far are true tumor rejection antigens, it is necessary to generate a large number of tumorreactive, peptide-specific CTL ex vivo. Adoptive transfer of these CTL into the autologous patient will be evaluated.

The most effective cancer vaccines involve the incorporation of genes encoding tumor antigens into recombinant plasmid or viruses such as vaccinia, fowlpox, or adenovirus. Because tumor cells transduced with genes encoding cytokines or costimulatory molecules have been shown to elicit in vivo antitumor activity, the combination of cancer antigen genes with other genes encoding cytokines such as IL-2 and costimulatory molecules such as B7.1 may enhance the immune response following viral infection. Alternatively, cancer vaccines using recombinant virus encoding tumor antigens can be enhanced by the exogenous administration of immunostimulatory cytokines (100). The major problem associated with recombinant viruses encoding tumor antigens is that patients develop strong antibody responses against the recombinant viruses, resulting in inefficient or low infection activity. "Naked" DNA vaccines are an alternative to the use of recombinant viruses. It has been shown that the injection of plasmid DNA encoding model tumor antigens directly into muscle or into the skin resulted in both cellular and humoral immune reactions (101).

\section{FUTURE DIRECTIONS}

The current cDNA cloning approach requires the determination of a restriction element for $\mathrm{T}$ cells. In some cases, it is difficult to determine which restriction molecule is used because of the point mutation of tumor antigens or unique tumor antigens. To overcome this problem, a retroviralbased cDNA expression system is being developed for the cloning of tumor antigens without information on restriction presentation. This will facilitate the identification of tumor antigens restricted by different MHC class I molecules.

Since successful vaccination may require both $\mathrm{CD}^{+}$and $\mathrm{CD} 8^{+} \mathrm{T}$ cells, it is important to develop systems for cloning MHC class II-restricted tumor antigens. Utilization of MHC class I-and II-restricted cancer peptides combined with cytokines and costimulatory molecules may mount an improved antitumor response against human cancer.

The majority of tumor antigens identified to 
date are melanoma antigens. It is important to extend our studies in melanoma to other tumors such as breast and prostate cancers. However, there are technical problems that need to be solved, including difficulties in generating CTL against breast and prostate tumor cells and a lack of knowledge of the putative tumor antigens expressed by these tumors. One approach is to clone tumor antigens shared by many types of tumors, including breast and prostate cancers, by the use of CTL clones derived from melanomareactive TIL. Several examples, including MAGE-1, MAGE-3, BAGE, GAGE, and CAG-3/ NY-ESO-1, are well documented. Of particular interest, CAG-3/NY-ESO-1 is expressed in $30 \%$ of breast, $25 \%$ of prostate, and $80 \%$ of bladder cancers.

The second strategy is the "reverse immunology" approach. In general, tumor antigens are overexpressed in the tumor compared with the normal counterpart, making them potential targets for immunotherapy. Recently developed DNA microchip technology will provide new opportunities to test and evaluate the gene expression pattern on a large scale. DNA microchip technology allows one to load thousands of cDNAs or to synthesize potentially hundreds of thousands of oligonucleotide probes on a chip $(102,103)$. With this technology, one is able to quickly monitor the expression of thousands of genes or to detect mutations in a gene of interest in a single chip. The availability of a large amount of information from the Human Genomic Project and many cDNA databases has made this approach feasible. A recent study using a cDNA microarray showed that TRP-1/gp75, which was previously shown to be recognized by CTL, was among the genes detected with a high level of expression in melanoma cells (104). This is in agreement with our Northern blot results showing that TRP-1/gp75 is expressed 10-fold higher in melanoma than in normal melanocytes (16). Evaluation of the changes in gene expression in cancer cells versus normal cells may allow us to define genes associated with malignancy and to identify potential tumor antigens. Once we have a few candidate genes in hand, the next step will be to generate antigen-specific CTL and test for their ability to recognize tumor cells. Improvement of quick and efficient methods for generating antigen-specific CTL will enhance our ability to identify tumor antigens.

In conclusion, the identification of human tumor antigens has provided a great opportunity for the development of effective cancer vaccines against cancer. Improvement of methods for generating CTL in vitro for breast, prostate, and other type of cancers and development of strategies for cloning MHC class II tumor antigens are important challenges. Cancer vaccines based on the identification of genes encoding tumor antigens combined with different adjuvants, cytokines, and costimulatory molecules need to be evaluated.

\section{ACKNOWLEDGMENTS}

I thank Samuel Johnston and Sue Hoffman for assistance in preparing this manuscript.

\section{REFERENCES}

1. Rosenberg SA, Spiess P, Lafreniere R. (1986) A new approach to the adoptive immunotherapy of cancer with tumor-infiltrating lymphocytes. Science 233: 13181321.

2. Kast WM, Offringa R, Peters PJ, Voordouw AC, Meloen RH, Van der Eb AJ, Melief CJM. (1989) Eradication of adenovirus E1induced tumors by E1A specific cytotoxic $\mathrm{T}$ lymphocytes. Cell 59: 603-614.

3. Greenberg PD. (1991) Adoptive T cell therapy of tumors: Mechanisms operative in the recognition and elimination of tumor cells. Adv. Immunol. 49: 281-355.

4. Rosenberg SA, Packard BS, Aebersold PM, Solomon D, Topalian SL, Toy ST, Simon P, Lotze MT, Yang JC, Seipp CA, Simpson C, Carter C, Bock S, Schwartzentruber D, Wei JP, White DE. (1988) Use of tumor infiltrating lymphocytes and interleukin-2 in the immunotherapy of patients with metastatic melanoma. Preliminary report. N. Engl. J. Med. 319: 1676-1680.

5. Rosenberg SA. (1992) The immunotherapy and gene therapy of cancer. J. Clin. Oncol. 10: $180-199$.

6. Brichard V, Van Pel A, Wölfel T, Wölfel C, De Plaen E, Lethië B, Coulie P, Boon T. (1993) The tyrosinase gene codes for an antigen recognized by autologous cytolytic $\mathrm{T}$ lymphocytes on HLA-A2 melanomas. $J$. Exp. Med. 178: 489-495.

7. Coulie PG, Brichard V, Van Pel A, Wolfel T, Schneider J, Traversari C, Mattei S, De Plaen ED, Lurquin C, Szikora J-P, Reauld J-C, Boon T. (1994) A new gene coding for 
a differentiation antigen recognized by autologous cytolytic $\mathrm{T}$ lymphocytes on HLA-A2 melanomas. J. Exp. Med. 180: 3542.

8. Van der Bruggen $P$, Traversari $C$, Chomez $P$, Lurquin C, DePlaen E, Van Den Eynde B, Knuth A, Boon T. (1991) A gene encoding an antigen recognized by cytolytic $\mathrm{T}$ lymphocytes on a human melanoma. Science 254: $1643-1647$.

9. Gaugler B, Van Den Eynde B, Van der Bruggen P, Romero P, Gaforio JJ, De Plaen E, Lethe B, Brasseur F, Boon T. (1994) Human gene MAGE-3 codes for an antigen recognized on a melanoma by autologous cytolytic T lymphocytes. J. Exp. Med. 179: 921-930.

10. Van Den Eynde B, Peeters O, De Backer O, Gaugler B, Lucas S, Boon T. (1995) A new family of genes coding for an antigen recognized by autologous cytolytic $\mathrm{T}$ lymphocytes on a human melanoma. J. Exp. Med. 182: 689-698.

11. Boel P, Wildmann C, Sensi ML, Brasseur R, Renauld JC, Coulie P, Boon T, Van der Bruggen P. (1995) BAGE: A new gene encoding an antigen recognized on human melanomas by cytolytic T lymphocytes. Immunity 2: 167-175.

12. Robbins PF, El-Gamil M, Kawakami Y, Stevens E, Yannelli J, Rosenberg SA. (1994) Recognition of tyrosinase by tumor infiltrating lymphocytes from a patient responding to immunotherapy. Cancer Res. 54: 3124-3126.

13. Wang RF, Robbins PF, Kawakami Y, Kang $X Q$, Rosenberg SA. (1995) Identification of a gene encoding a melanoma tumor antigen recognized by HLA-A31-restricted tumor-infiltrating lymphocytes. J. Exp. Med. 181: 799-804.

14. Wolfel T, Hauer M, Schneider J, Serrano M, Wolfel C, Klehmann-Hieb E, De Plaen E, Hankeln T, Meyer Zum Buschenfelde $\mathrm{K}-\mathrm{H}$, Beach D. (1995) A pl6INK4a-insensitive CDK4 mutant targeted by cytolytic T lymphocytes in a human melanoma. Science 269: 1281-1284.

15. Robbins PF, El-Gamil M, Li YF, Kawakami Y, Loftus D, Appella E, Rosenberg SA. (1996) A mutated $\beta$-catenin gene encodes a melanoma-specific antigen recognized by tumor infiltrating lymphocytes. J. Exp. Med. 183: 1185-1192.

16. Wang RF, Appella E, Kawakami Y, Kang X,
Rosenberg SA. (1996) Identification of TRP-2 as a human tumor antigen recognized by cytotoxic T lymphocytes. J. Exp. Med. 184: 2207-2216.

17. Mandelbolm O, Berke G, Fridkin M, Feldman M, Eisenstein M, Eisenbach L. (1994) CTL induction by a tumor-associated antigen octapeptide derived from a murine lung carcinoma. Nature 369: 67-71.

18. Blake J, Johnston JV, Hellstrom KE, Marqardt H, Chen L. (1996) Use of combinatorial peptide libraries to construct functional mimics of tumor epitopes recognized by MHC class I-restricted cytolytic T lymphocytes. J. Exp. Med. 184: 121-130.

19. Cheever MA, Disis ML, Bernhard $\mathrm{H}$, Gralow JR, Hand SL, Huseby ES, Qin HL, Takahashi M, Chen W. (1995) Immunity to oncogenic proteins. Immunol. Rev. 145: 3359.

20. Fisk B, Blevins TL, Wharton JT, Ioannides CG. (1995) Identification of an immunodominant peptide of HER-2/neu protooncogene recognized by ovarian tumorspecific cytotoxic T lymphocyte lines. J. Exp. Med. 181: 2109-2117.

21. Jung S, Schluesener HJ. (1991) Human T lymphocytes recognize a peptide of single point-mutated, oncogenic ras proteins. $J$. Exp. Med. 173: 273-276.

22. Skipper J, Stauss HJ. (1993) Identification of two cytotoxic $\mathrm{T}$ lymphocyte-recognized epitopes in the ras protein. J. Exp. Med. 177: 1493-1498.

23. Celis E, Tsai V, Crimi C, DeMars R, Wentworth PA, Chesnut RW, Grey HM, Sette A, Serra HM. (1994) Induction of anti-tumor cytotoxic $\mathrm{T}$ lymphocytes in normal humans using primary cultures and synthetic peptide epitopes. Proc. Natl. Acad. Sci. U.S.A. 91: 2105-2109.

24. Rammensee HG, Friede $T$, Stevanoviic $S$. (1995) MHC ligands and peptide motifs: First listing. Immunogenetics 41: 178-228.

25. Bouchard B, Fuller BB, Vijayasaradhi S, Houghton AN. (1989) Induction of pigmentation in mouse fibroblasts by expression of human tyrosinase cDNA. J. Exp. Med. 169: 2029-2042.

26. Wolfel T, Van Pel A, Brichard V, Schneider J, Seliger B, Meyer Zum Buschenfelde K-H, Boon T. (1994) Two tyrosinase nonapeptides recognized on HLA-A2 melanomas by autologous cytolytic T lymphocytes. Eur. J. Immunol. 24: 759-764. 
27. Brichard VG, Herman J, Van Pel A, Wildmann C, Gaugler B, Wolfel T, Boon T, Lethe B. (1996) A tyrosinase nonpeptide presented by HLA-B44 is recognized on a human melanoma by autologous cytolytic T lymphocytes. Eur. J. Immunol. 26: 224230.

28. Skipper JC, Hendrickson RC, Gulden PH, Brichard V, Van Pel A, Chen Y, Shabanowitz J, Wolfel T, Slingluff CL, Boon T, Hunt D. (1996) An HLA-A2-restricted tyrosinase antigen on melanoma cells results from posttranslational modification and suggests a novel pathway for processing of membrane proteins. J. Exp. Med. 183: 527-534.

29. Markus NR, Rosenberg SA, Topalian SL. (1995) Analysis of cytokine secretion by melanoma-specific $\mathrm{CD}^{+} \mathrm{T}$ lymphocytes. J. Interferon Cytokine Res. 15: 739-746.

30. Dadmarz R, Sgagias MK, Rosenberg SA, Schwartzentruber DJ. (1995) $\mathrm{CD}^{+}{ }^{+} \mathrm{T}$ lymphocytes infiltrating human breast cancer recognize autologous tumor in an MHCclass II restricted fashion. Cancer Immunol. Immunother. 40: 1-9.

31. Topalian SL, Rivoltini L, Mancini M, Markus NR, Robbins PF, Kawakami Y, Rosenberg SA. (1994) Human CD4 ${ }^{+} \mathrm{T}$ cells specifically recognize a shared melanomaassociated antigen encoded by the tyrosinase gene. Proc. Natl. Acad. Sci. U.S.A. 91: 9461-9465.

32. Topalian SL, Rivoltini L, Mancini M, Ng J, Hartzman RJ, Rosenberg SA. (1994) Melanoma-specific $\mathrm{CD}^{+}{ }^{+} \mathrm{T}$ lymphocytes recognize human melanoma antigens processed and presented by Epstein-Barr-transformed B cells. Int. J. Cancer 58: 69-79.

33. Topalian SL, Gonzales ML, Parkhurst M, Li YF, Southwood S, Rosenberg SA, Robbins PF. (1996) Melanoma-specific CD4 ${ }^{+} \mathrm{T}$ cells recognize nonmutated HLA-DR-restricted tyrosinase epitopes. J. Exp. Med. 183: 19651971.

34. Takahashi T, Chapman PB, Yang SY, Hara I, Vijayasaradhi S, Houghton AN. (1995) Reactivity of autologous $\mathrm{CD}^{+} \mathrm{T}$ lymphocytes against human melanoma. Evidence for a shared melanoma antigen presented by HLA-DR15. J. Immunol. 154: 772-779.

35. Kawakami Y, Eliyahu S, Delgaldo $\mathrm{CH}$, Robbins PF, Rivoltini L, Topalian SL, Miki T, Rosenberg SA. (1994) Cloning of the gene coding for a shared human melanoma antigen recognized by autologous $\mathrm{T}$ cells infil- trating into tumor. Proc. Natl. Acad. Sci. U.S.A. 91: 3515-3519.

36. Kawakami Y, Eliyahu S, Sakaguchi K, Robbins PF, Rivoltini L, Yannelli JB, Appella E, Rosenberg SA. (1994) Identification of the immunodominant peptides of the MART-1 human melanoma antigen recognized by the majority of HLA-A2 restricted tumor infiltrating lymphocytes. J. Exp. Med. 180: 347-352.

37. Sensi $M$, Traversari $C$, Radrizzani $M$, Salvi S, Maccalli C, Mortarini R, Rivoltini L, Farina $C$, Nicolini $G$, Wolfel $T$, Brichard $V$, Boon T, Bordignon C, Anichini A, Parmiani G. (1995) Cytotoxic T lymphocyte clones from different patients display limited T-cell receptors variable gene usage in HLA-A2 restricted recognition of Melan/Mart-1 melanoma antigen. Proc. Natl. Acad. Sci. U.S.A. 92: 5674-78.

38. Kawakami $Y$, Eliyahu $S$, Jennings $C$, Sakaguchi K, Kang X, Southwood S, Robbins PF, Sette A, Appella E, Rosenberg SA. (1995) Recognition of multiple epitopes in the human melanoma antigen gpl00 by tumor-infiltrating $\mathrm{T}$ lymphocytes associated with in vivo tumor regression. J. Immunol. 154: 3961-3968.

39. Bakker ABH, Schreurs MWJ, de Boer AJ, Kawakami Y, Rosenberg SA, Adema GJ, Figdor CG. (1994) Melanocyte lineage-specific antigen gp100 is recognized by melanocyte-derived tumor-infiltrating lymphocytes. J. Exp. Med. 179: 1005-1009.

40. Kawakami $\mathrm{Y}$, Eliyahu S, Delgado $\mathrm{CH}$, Robbins PF, Sakaguchi K, Appella E, Yannelli JR, Adema GJ, Miki T, Rosenberg SA. (1994) Identification of a human melanoma antigen recognized by tumor infiltrating lymphocytes associated with in vivo tumor rejection. Proc. Natl. Acad. Sci. U.S.A. 91: 6458-6462.

41. Adema GJ, de Boer AJ, van't Hullenaar R, Denijn M, Ruiter DJ, Vogel AM, Figdor CG. (1993) Melanocyte lineage-specific antigens recognized by monoclonal antibodies NK1-bete, HMB-50, and HMB-45 are encoded by a single cDNA. Am. J. Pathol. 143: 1579-1585.

42. Bakker A, Schreurs M, Tafazzul G, de Boer A, Kawakami Y, Adema G, Figdor C. (1995) Identification of a novel peptide derived from the melanocyte-specific gp100 antigen as the dominant epitope recognized by 
an HLA-A2.1-restricted anti-melanoma CTL line. Int. J. Cancer 62: 97-102.

43. Skipper JCA, Kittlesen DJ, Hendrickson RA, Deacon DD, Harthun NL, Wagner SN, Hunt DF, Engelhard VH, Slingluff CL. (1996) Shared epitopes for HLA-A3-restricted melanoma-reactive human CTL include a naturally processed epitope from Pmel-17/gpl00. J. Immunol. 157: 50275033.

44. Cox AL, Skipper J, Cehn Y, Henderson RA, Darrow TL, Shabanowitz J, Engelhard VH, Hunt DF, Slingluff CL. (1994) Identification of a peptide recognized by five melanomaspecific human cytotoxic T cell lines. Science 264: 716-719.

45. Topalian S, Solomon D, Avis FP, Chang AE, Freeksen DL, Linehan WM, Lotze MT, Robertson CN, Seipp CA, Simon P, Simpson CG, Rosenberg SA. (1988) Immunotherapy of patients with advanced cancer using tumor infiltrating lymphocytes and recombinant interleukin-2: A pilot study. J. Clin. Oncol. 6: 839-853.

46. Mattes MJ, Thomson TM, Old LJ, Lloyd KO. (1983) A pigmentation-associated, differentiation antigen of human melanoma defined by a precipitating antibody in human serum. Int. J. Cancer 32: 717-721.

47. Thomson TM, Real FX, Murakami S, Cordon-Cardo C, Old LJ, Houghton AN. (1988) Differentiation antigens of melanocytes and melanoma: Analysis of melanosome and cell surface markers of human pigmented cells with monoclonal antibodies. J. Invest. Dermatol. 90: 459-466.

48. Thomson TM, Mattes JM, Roux L, Old LJ, Lloyd KO. (1985) Pigmentation-associated glycoprotein of human melanoma and melanocytes: Definition with a mouse monoclonal antibody. J. Invest. Dermatol. 85: 169174.

49. Jimenez-Cervantes C, Solano F, Kobayashi T, Urabe K, Hearing VJ, Lozano JA, GarciaBorron JC. (1994) A new enzymatic function in the melanogenic pathway. J. Biol. Chem. 269: 17993-18001.

50. Falk K, Rotzschke O, Takiguchi M, Grahovae B, Gnau V, Stevanovic S, Jung G, Rammensee H-G. (1994) Peptide motifs of HLA-Al, -A11, -A31, and -A33 molecules. Immunogenetics 40: 238-241.

51. Wang RF, Parkhurst MR, Kawakami Y, Robbins PF, Rosenberg SA. (1996) Utilization of an alternative open reading frame of a normal gene in generating a novel human cancer antigen. J. Exp. Med. 183: 11311140.

52. Shaw MW, Choppin PW, Lamb RA. (1983) A previously unrecognized influenza B virus glycoprotein from a bicistronic mRNA that also encodes the viral neuraminidase. Proc. Natl. Acad. Sci. U.S.A. 80: 4879-4883.

53. Spiropoulou CF, Nichol ST. (1993) A small, highly basic protein is encoded in overlapping frame within the $\mathrm{P}$ gene of vesicular stomatitis virus. J. Virol. 67: 3103-3110.

54. Schwartz S, Felber BK, Pavlakis GN. (1992) Mechanism of translation of monocistronic and multicistronic human immunodeficiency virus type 1 mRNAs. Mol. Cell. Biol. 12: 207-219.

55. Serrano M, Hannon GJ, Beach D. (1993) A new regulatory motif in cell-cycle control causing specific inhibition of cyclin D/ CDK4 [see comments]. Nature 366: 704707.

56. Sherr CJ, Roberts JM. (1995) Inhibitors of mammalian Gl cyclin-dependent kinases. Genes Dev. 9: 1149-1163.

57. Quelle DE, Zindy F, Ashmun RA, Sherr CJ. (1995) Alternative reading frames of the INK4a tumor suppressor gene encode two unrelated proteins capable of inducing cell cycle arrest. Cell 83: 993-1000.

58. Malarkannan S, Afkarian $M$, Shastri N. (1995) A rare cryptic translation product is presented by $\mathrm{Kb}$ major histocompatibility complex class I molecule to alloreactive $\mathrm{T}$ cells. J. Exp. Med. 182: 1739-1750.

59. Robbins P, El-Gamil M, Li YF, Fitzgerald E, Kawakami Y, Rosenberg SA. (1997) The intronic region of an incompletely spliced gp100 gene transcript encodes an epitope recognized by melanoma-reactive tumorinfiltrating lymphocytes. J. Immunol. 159: 303-308.

60. Bloom MB, Perry-Lalley D, Robbins PF, Li Y, El-Gamil M, Rosenberg SA, Yang JC. (1997) Identification of tyrosinase-related protein 2 as a tumor rejection antigen for the Bl6 melanoma. J. Exp. Med. 185: 453460.

61. Sidney J, Grey HM, Kubo RT, Sette A. (1996) Practical, biochemical and evolutionary implications of the discovery of HLA class I supermotifs. Immunol. Today 17: 261-266.

62. Wang R, Johnston S, Southwood S, Sette A, Rosenberg SA. (1997) Recognition of an 
antigenic peptide derived from TRP-2 by cytotoxic $\mathrm{T}$ lymphocytes in the context of HLA-A31 and -A33. J. Immunol. In press.

63. Traversari $C$, Van der Bruggen $P$, Luescher IF, Lurquin C, Chomez P, Van Pel A, De Plaen E, Amar-Costesec A, Boon T. (1992) A nonapeptide encoded by human gene MAGE- 1 is recognized on HLA-Al by cytolytic $\mathrm{T}$ lymphocytes directed against tumor antigen MZ2-E. J. Exp. Med. 176: 14531457.

64. Van der Bruggen $\mathrm{P}$, Szikora J-P, Boel $\mathrm{P}$, Wildmann C, Somville M, Sensi M, Boon T. (1994) Autologous cytolytic T lymphocytes recognize a MAGE-1 nonapeptide on melanomas expressing Cw1601. Eur. J. Immunol. 24: 2134-2140.

65. Van der Bruggen $P$, Bastin J, Gajewski T, Coulie PG, Boel P, de Smet C, Traversari C, Townsend A, Boon T. (1994) A peptide encoded by human gene MAGE-3 and presented by HLA-A2 induces cytolytic T lymphocytes that recognize tumor cells expressing MAGE-3. Eur. J. Immunol. 24: 3038-3043.

66. Chen YT, Scanlan MJ, Sahin U, Tureci O, Gure AO, Tsang S, Williamson B, Stockert E, Pfreundschuh M, Old LJ. (1997) A testicular antigen aberrantly expressed in human cancers detected by autologous antibody screening. Proc. Natl. Acad. Sci. U.S.A. 94: 1914-1918.

67. Van Elsas A, Nijman HW, Van der Minne CE, Mourer JS, Kast WM, Melief CJ, Schrier PI. (1995) Induction and characterization of cytotoxic T-lymphocytes recognizing a mutated $\mathrm{p} 21$ ras peptide presented by HLA-A*0201. Int. J. Cancer 61: 389-396.

68. Houbiers JGA, Nijman HW, van der Burg SH, Drijfhout JW, Kenemans P, van de Velde $\mathrm{CJH}$, Brand A, Momburg F, Kast WM, Melief CJM. (1993) In vitro induction of human cytotoxic $\mathrm{T}$ lymphocyte responses against peptides of mutant and wild-type p53. Eur. J. Immunol. 23: 2072 2077.

69. Nijman $\mathrm{HW}$, van der Burg $\mathrm{SH}$, Vierboom MP, Houbiers JG, Kast WM, Melief CJ. (1994) p53, a potential target for tumordirected T cells. Immunol. Lett. 40: 171-178.

70. Nijman HW, Houbiers JGA, van der Burg SH, Vierboom MPM, Kenemans P, Kast WM, Melief CJM. (1993) Characterization of cytotoxic $\mathrm{T}$ lymphocyte epitopes of a selfprotein, p53, and a non-self-protein, influ- enza matrix: Relationship between major histocompatibility complex peptide binding affinity and immune responsiveness to peptides. Immunotherapy 14: 121-126.

71. Theobald M, Biggs J, Dittmer D, Levine AJ, Sherman LA. (1995) Targeting p53 as a general tumor antigen. Proc. Natl. Acad. Sci. U.S.A. 92: 11993-11997.

72. Coulie PG, Lehmann F, Lethe B, Herman J, Lurquin C, Andrawiss M, Boon T. (1995) A mutated intron sequence codes for an antigenic peptide recognized by cytolytic $\mathrm{T}$ lymphocytes on a human melanoma. Proc. Natl. Acad. Sci. U.S.A. 92: 7976-7980.

73. Grunwald GB. (1993) The structural and functional analysis of cadherin calcium-dependent cell adhesion molecules. Curr. Opin. Cell. Biol. 5: 797-805.

74. Hoschuetzky H, Aberle H, Kemler R. (1994) $\beta$-catenin mediates the interaction of the cadherin-catenin complex with epidermal growth factor receptor. J. Cell. Biol. 127: $1375-1380$.

75. Becker K-F, Atkinson MJ, Reich U, Becker I, Nekarda H, Siewert JR, Hofler H. (1994) E-cadherin gene mutations provide clues to diffuse type gastric carcinomas. Cancer Res. 54: 3845-3852.

76. Kawanishi J, Kato J, Sasaki K, Fujii S, Watanabe N, Niitsu Y. (1995) Loss of E-cadherin-dependent cell-cell adhesion due to mutation of the $\beta$-catenin gene in a human cancer cell line, HSC-39. Mol. Cell. Biol. 15: $1175-1181$.

77. Korinek V, Baker N, Morin PJ, van Wichen D, de Weger R, Kinzler KW, Vogelstein B, Clevers H. (1997) Constitutive transcriptional activation by a beta-catenin-Tcf complex in APC $-1-$ colon carcinoma. Science 275: 1784-1787.

78. Morin PJ, Sparks AB, Korinek V, Barker N, Clevers $\mathrm{H}$, Vogelstein B, Kinzler KW. (1997) Activation of beta-catenin-Tcf signaling in colon cancer by mutations in betacatenin or APC. Science 275: 1787-1790.

79. Rubinfeld B, Robbins $\mathrm{P}$, El-Gamil M, Albert I, Porfiri E, Polakis P. (1997) Stabilization of beta-catenin by genetic defects in melanoma cell lines. Science 275: 1790-1792.

80. Brandle D, Brasseur F, Weynants $\mathrm{P}$, Boon T, Van Den Eynde B. (1996) A mutated HLA-A2 molecule recognized by autologous cytotoxic $\mathrm{T}$ lymphocytes on a human renal cell carcinoma. J. Exp. Med. 183: 2501-2508. 
81. Robbins PF, El-Gamil M, Li YF, Topalian SL, Rivoltini L, Sakaguchi K, Appella E, Kawakami Y, Rosenberg SA. (1995) Cloning of a new gene encoding an antigen recognized by melanoma-specific HLA-A24 restricted tumor-infiltrating lymphocytes. J. Immunol. 154: 5944-5950.

82. Ioannides CG, Fisk B, Pollack MS, Frazier ML, Wharton JT, Freedman RS. (1993) Cytotoxic T-cell clones isolated from ovarian tumour infiltrating lymphocytes recognize common determinants on nonovarian tumour clones. Scand. J. Immunol. 37: 413424.

83. Yoshino I, Peoples GE, Geoedegebauure PS, Mazizrz R, Eberlein TJ. (1994) Association of HER2/neu expression with sensitivity to tumor-specific CTL in human ovarian cancer. J. Immunol. 152: 2393-2400.

84. Disis ML, Calenoff E, McLaughlin G, Murphy $\mathrm{AE}$, Chen W, Groner B, Jeschke $M$, Lydon N, McGlynn E, Livingston RB, Moe R, Cheever MA. (1994) Existent T cell and antibody immunity to HER-2/neu protein in patients with breast cancer. Cancer Res. 54: 16-20.

85. Peoples GE, Goedegebuure PS, Smith R, Linehan DC, Yoshino I, Eberlein TJ. (1995) Breast and ovarian cancer-specific cytotoxic T lymphocytes recognize the same HER2/ neu-deroed peptide. Proc. Natl. Acad. Sci. U.S.A. 92: 432-436.

86. Linehan DC, Goedegebuure PS, Peoples GE, Rogers SO, Eberlein TJ. (1995) Tumorspecific and HLA-A2-restricted cytolysis by tumor-associated lymphocytes in human metastatic breast cancer. J. Immunol. 155: 4486-4491.

87. Ionaaides $C G$, Fisk $B$, Jerome $K R$, Irimura T, Wharton JT, Finn OJ. (1993) Cytotoxic T cells from ovarian malignant tumors can recognize polymorphic epithelial mucin core peptides. J. Immunol. 151: 3693-3703.

88. Magarian-Blander J, Domenech N, Finn OJ. (1993) Specific and effective T-cell recognition of cells transfected with a truncated human mucin cDNA. Ann. N.Y. Acad. Sci. 690: 231-243.

89. Finn OJ, Jerome KR, Henderson RA, Pecher G, Domenech N, Magarian-Blander J, Barratt-Boyes SM. (1995) MUC-i epithelial tumor mucin-based immunity and cancer vaccines. Immunol. Rev. 145: 61-89.

90. Houghton AN. (1994) Commentary: Can- cer antigens: Immune recognition of self and alterted self. J. Exp. Med. 180: 1-4.

91. Nanda NK, Sercarz EE. (1995) Induction of anti-self-immunity to cure cancer. Cell 82: 13-17.

92. Nordlund JJ, Kirkwood M, Forget BM, Milton G, Albert DM, Lerner AB. (1983) Vitiligo in patients with metastatic melanoma: A good prognostic sign. J. Am. Acad. Dermatol. 9: 689-695.

93. Bystryn J-C, Rigel D, Friedman RJ, Kopf A. (1987) Prognostic significance of hypopigmentation in malignant melanoma. Arch. Dermatol. 123: 1053-1055.

94. Richards JM, Mehta N, Ramming K, Skosey P. (1992) Sequential chemoimmunotherapy in the treatment of metastatic melanoma. J. Clin. Oncol. 10: 1338-1343.

95. Visseren MJ, Van Elsas A, van der Voort EI, Ressing ME, Kast WM, Schrier PI, Melief CJ. (1995) CTL specific for the tyrosinase autoantigen can be induced from healthy donor blood to lyse melanoma cells. J. Immunol. 154: 3991-3998.

96. Hara I, Takechi Y, Houghton AN. (1995) Implicating a role for immune recognition of self in tumor rejection: Passive immunization against the Brown locus protein. $J$. Exp. Med. 182: 1609-1614.

97. Young JW, Inaba K. (1996) Dendritic cells as adjuvants for class I major histocompatibility complex-restricted antitumor immunity. J. Exp. Med. 183: 7-11.

98. Henderson RA, Nimgaonkar MT, Watkins SC, Robbins PD, Ball ED, Finn OJ. (1996) Human dendritic cells genetically engineered to express high levels of the human epithelial tumor antigen mucin (MUC-1). Cancer Res. 56: 3763-3770.

99. Reeves ME, Royal RE, Lam JS, Rosenberg SA, Hwu P. (1996) Retroviral transduction of human dendritic cells with a tumor-associated antigen gene. Cancer Res. 56: 56725677.

100. Bronte V, Tsung K, Rao JB, Chen PW, Wang M, Rosenberg SA, Restifo NP. (1995) IL-2 enhances the function of recombinant poxvirus-based vaccines in the treatment of established pulmonary metastases. J. Immunol. 154: 5282-5292.

101. Irvine K, Rao J, Rosenberg S, Restifo N. (1995) Cytokine enhancement of DNA immunization leads to treatment of established pulmonary metastases. J. Immunol. 156: $238-245$. 
102. Schena M, Shalon D, Davis RW, Brown PO. (1995) Quantitative monitoring of gene expression patterns with a complementary DNA microarray. Science 270: 467-470.

103. Chee $M$, Yang R, Hubbell E, Berno A, Huang XC, Stern D, Winlker J, Lockhart DJ, Morris MS, Fodor SP. (1996) Accessing genetic information with high-density DNA arrays. Science 274: 610-614.

104. DeRisi J, Penland L, Brown PO, Bittner ML, Meltzer PS, Ray M, Chen Y, Su YA, Trent JM. (1996) Use of a cDNA microarray to analyse gene expression patterns in human cancer. Nature Genet. 14: 457-460. 